\title{
Complementarity of acquisition techniques for the documentation of Neolithic engravings: lasergrammetric and photographic recording in Gavrinis passage tomb (Brittany, France)
}

\author{
Serge Cassen ${ }^{\mathrm{a}, *}$, Laurent Lescop ${ }^{\mathrm{b}}$, Valentin Grimaud ${ }^{\mathrm{c}}$, Guillaume Robin ${ }^{\mathrm{d}}$ \\ ${ }^{a}$ CNRS, Laboratoire de recherches archéologiques (UMR 6566), Université de Nantes, rue de la Censive du Tertre, BP 81227, 44312 Nantes, France \\ ${ }^{\mathrm{b}}$ Ecole nationale supérieure d'architecture (UMR 6566), 6 quai François Mitterrand, 44262 Nantes, France \\ ${ }^{c}$ Laboratoire de recherches archéologiques (UMR 6566), Université de Nantes et Ecole nationale supérieure d'architecture, 44312 Nantes, France \\ ${ }^{\mathrm{d}}$ McDonald Institute for Archaeological Research, University of Cambridge, Downing Street, Cambridge CB2 3ER, UK
}

Keywords:

Neolithic engravings

Megalithic tomb

Brittany

Documentation techniques

Lasergrammetry

Photographic recording

Colorimetry

\begin{abstract}
A B S T R A C T
The Neolithic tomb of Gavrinis is famous for its rich and complex engraved art that has inspired a large number of interpretative studies. However, all of these are based on unsatisfactory drawings. This article describes the methodological results of a new project for recording the Gavrinis engravings that combines 3D laser and 2D photographic techniques. Laser scanning not only provides accurate contextual information such as the stone relief and architectural setting in which the art is found. Specially designed processing of point clouds also makes it possible to highlight the contours of the pecked motifs and to record them directly from the 3D model of the decorated stones. This can be further improved by photography using oblique lighting and image processing techniques in order to obtain more detailed recordings of the motifs as well as insights into their chronological relationships. In the unusual case of barely visible engravings made with very slight peckmarks, experimental application of the DStretch colour detection programme has been unexpectedly successful. A comparison of all these results shows that laser and photographic techniques have different strengths and weaknesses that complement each other. Thus, combined use of these techniques within a single methodological process produces innovative and comprehensive documentation of Neolithic tomb art.
\end{abstract}

\section{Introduction}

The megalithic passage tomb on the small island of Gavrinis (Larmor-Baden, France; Fig. 1), consists of a large circular stone cairn (50 m wide, $7.5 \mathrm{~m}$ high, $6980 \mathrm{~m}^{3}$ ) covering an internal megalithic structure $16 \mathrm{~m}$ long composed of a quadrangular chamber $\left(5.5 \mathrm{~m}^{2}\right)$ and an access passage leading to the outside (Fig. 2). The wall, floor and ceiling surfaces of the internal structure are made of granite, migmatite, orthogneiss, quartz and sandstone slabs.

Gavrinis is one of the most famous Neolithic monuments in Europe for the quality and quantity of the abstract and figurative motifs that were pecked out all over the wall surface of the inner chamber. Following first official recognition of the site and its

\footnotetext{
* Corresponding author. Tel.: +33 (0) 240141107.

E-mail addresses: serge.cassen@univ-nantes.fr (S. Cassen), Laurent.lescop@ nantes.archi.fr (L. Lescop), valentin.grimaud@univ-nantes.fr (V. Grimaud), ger24@ cam.ac.uk (G. Robin).
}

engravings (Mérimée, 1836), excavations by Closmadeuc (1884 1886) enabled the completion of a first catalogue of the art at Gavrinis (Closmadeuc, 1873). More recent excavation by CharlesTanguy Le Roux (1985) resulted in the discovery of new spectacular carvings of horned animals on the upper face of the chamber capstone (Le Roux, 1984a,b). It was then realised that this large stone and its art refitted with another decorated capstone found $3.5 \mathrm{~km}$ away in the chambered tomb of La Table des Marchands at Locmariaquer (Closmadeuc, 1885; Le Roux, 1984a). Both fragments were originally part of the same monumental stele which, prior to its reuse in the construction of the two tombs, stood in a large stone row of which the famous broken Grand Menhir at Locmariaquer is the only remaining element in situ (Cassen and L'Helgouac'h 1992; Cassen, 2009).

Since the 19th century, the art of Gavrinis has been interpreted in many different ways through innumerable scholarly papers. However, all these interpretations were based on varying drawings made by archaeologists or artists. The best recordings so far were made 50-30 years ago by direct tracing (Shee Twohig, 1981; Le 


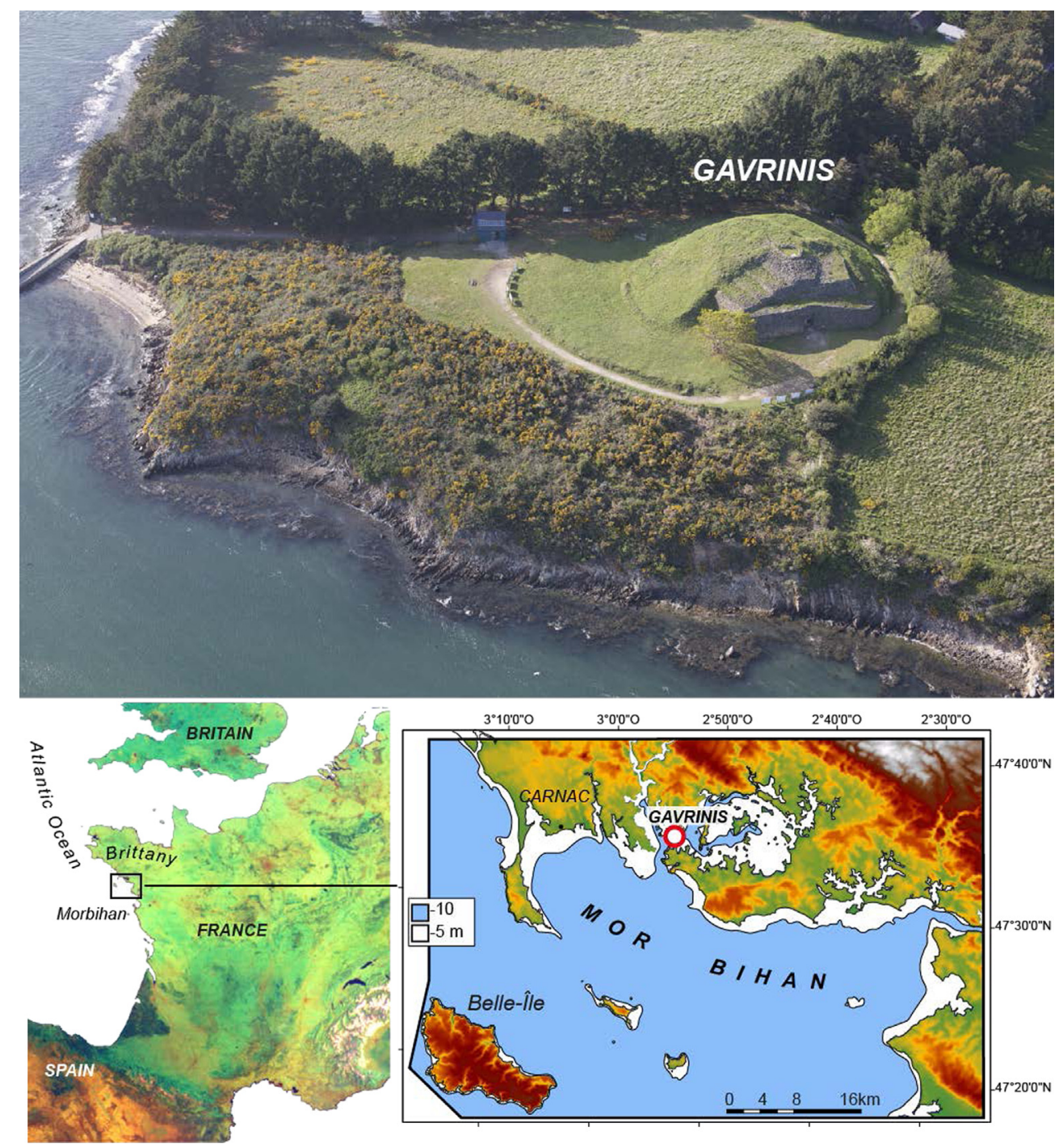

Fig. 1. Aerial view and location maps of the Neolithic cairn on Gavrinis island (Morbihan, France; photograph: Sagemor).

Roux, 1984a,b), a technique that often misses details of the engravings and, in all cases, only provides a schematic view of the morphology of the stone on which the art was made.

While new photographic recordings of selected engravings were initiated in 2009 as part of the ANR-funded JADE project (Pétrequin et al., 2012), it was only in 2011 that a full dedicated programme was launched for Gavrinis with, as a main objective, the creation of a new comprehensive corpus of the engraved art and of its architectural context. This project ("Gavrinis: à la recherche des représentations d'une tombe à couloir du IVe millénaire" 2011-2013) was built as an original collaboration between archaeologists from the CNRS and architects from the Nantes national school of architecture. Its aim was to improve the constant relationship - in archaeology, and in particular in any iconographic study - between acquisition, representation and interpretation of field data.

The technical challenge of the project was to create a comprehensive three-dimensional recording and virtual reconstruction of the whole monument of Gavrinis, from the huge mass of the cairn to the structural stones of the megalithic chamber and to the details of its engravings. In a recent technical overview of the project (Lescop et al., 2013), we described how 3D lasergrammetry and photogrammetry were used to record the architecture of the tomb and the geometry of the stones and engravings, and how light 3D models for interactive public presentation can be created from these data. In the present article, we would like to discuss a further step of the project and show how lasergrammetric techniques can be combined with photographic techniques in order to solve problems in the recording and interpretation of rock engravings.

The programme used and compared different types of $2 \mathrm{D}$ photographic and 3D laser techniques in order to record both the art and the stone relief. The resulting data have been incorporated into a single digital model, which enables for the first time total recording of the decorated stones. During the process, which was in large part experimental, the enhancing capacities of the two techniques were explored and compared in order to assess their ability to unveil unknown details of the engravings as well as chronological relationships within groups of signs. A third technique using photograph colorimetry was later successfully experimented, to identify very faint pecked motifs made on sandstone where other techniques had failed.

This article proposes to review these three documentation processes and to show how combined use of them is essential for detailed and accurate recording of both engraved and natural surface data in Neolithic tombs. Such data entirely change our 

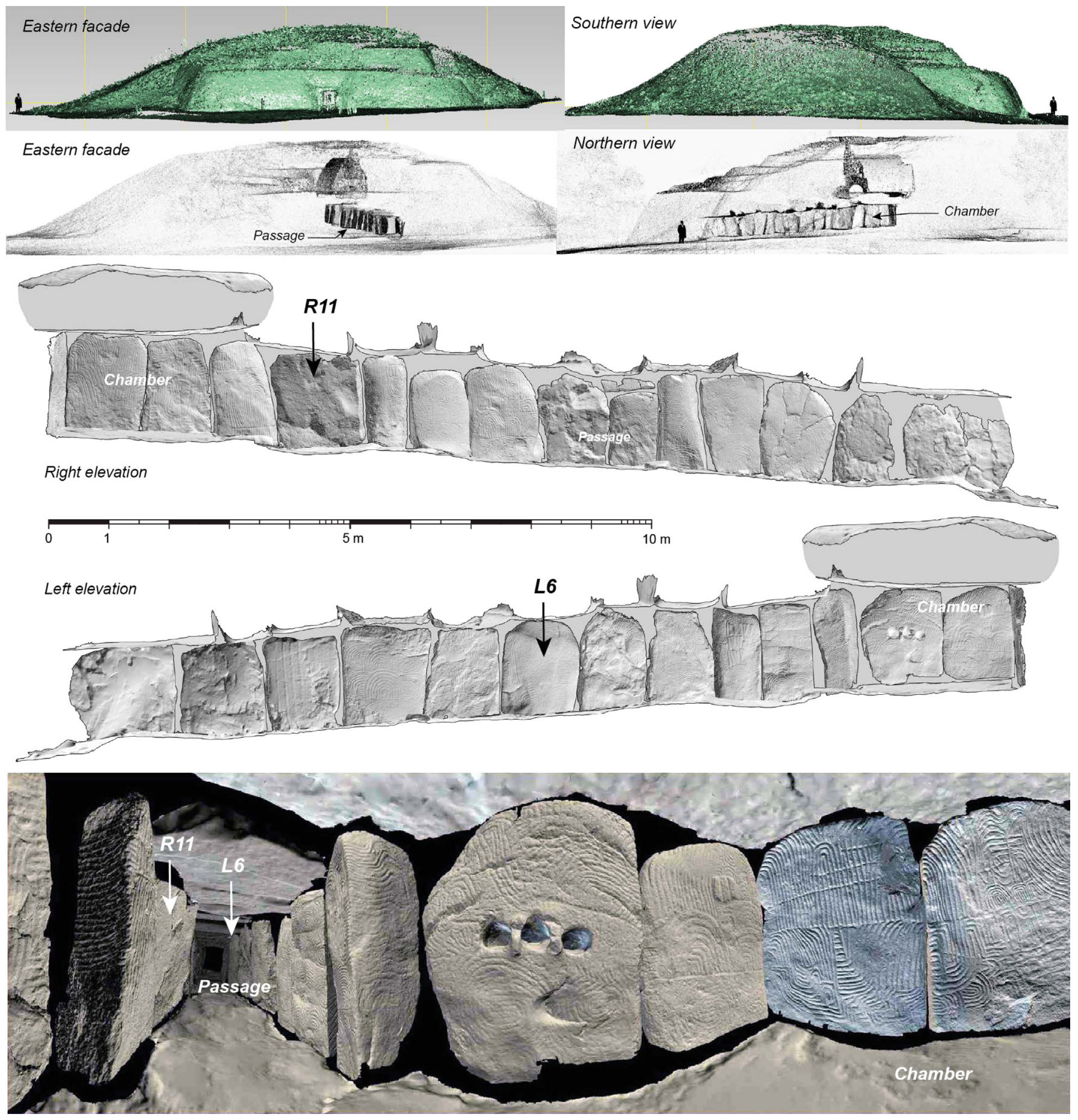

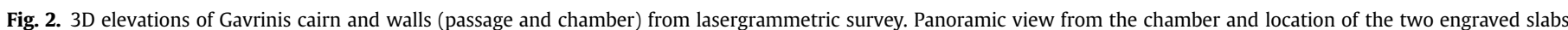
(R11 and L6) described in the text.

perception of the decorated stones and provide a completely new basis for interpretation of the art at Gavrinis.

Inevitably, the conceptual framework recently elaborated in order to re-think the signs and their combinations (Cassen, 2000) had an influence on the way these signs were documented and represented. For example, particular attention was given to hierarchical arrangements, oppositions and correlations of signs within engraved compositions. This back-and-forth reflection between methodology and epistemology has gradually become more accurate as similar recording has been conducted on other monuments in the region over the last 10 years (Runesto, Mané Croc'h, Bronzo, Vieux Moulin, Table des Marchands, Mané Kerioned, Mané Lud, Mané Rutual - Cassen, 2011). At Gavrinis, therefore, a last objective was to examine overlapping engravings in order to identify the chronological order of execution of the signs on each stone, and to investigate the semiotic relationships between groups of motifs on adjoining stones inside the tomb. 

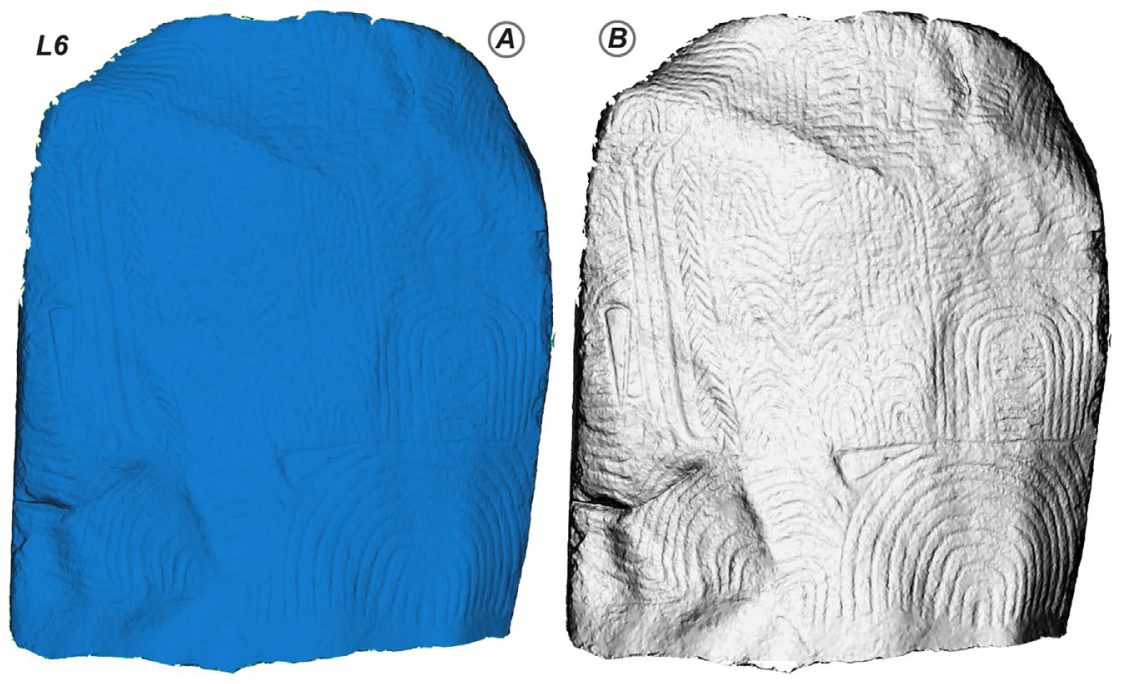

Fig. 3. Orthostat L6. On the left (A), view of the 3D model in Geomagic; on the right (B), same image after processing in Adobe Photoshop (shading by the normals).

\section{Methodological choices}

The principle of combining photographic and 3D laser techniques to record prehistoric rock art is not new (e.g. Pinçon and Geneste, 2010; Carrera Ramírez, 2011; Domingo et al. 2013). However, the application of this principle implies very different sets of methodological choices according to the context in which the art is found (cave, rock shelter, megalith, etc.), the geology of the rock surface and the nature of the art itself (painting, incision, carving, sculpture, etc.). A significant challenge in recording art and architecture at Gavrinis was to build new methodological processes specifically designed for the particularities of this Neolithic site, such as the morphology of the engravings (hollowed pecked lines),

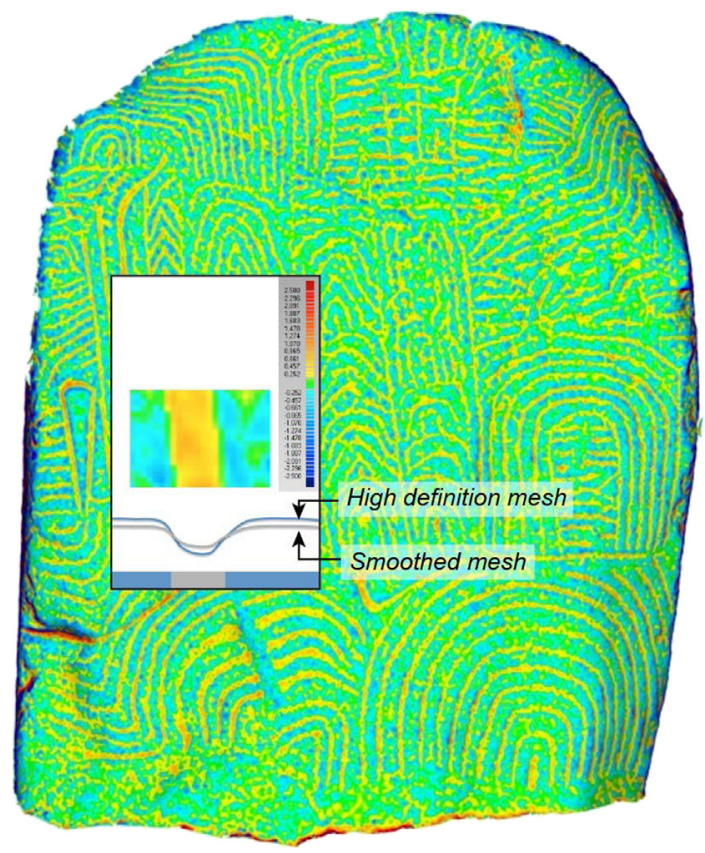

Fig. 4. Deviation map of orthostat L6 as set on " 440 " in Geomagic. Colour code shows the microtopographical differences between high resolution mesh and smoothed mesh of the points cloud. Hollow pecked areas (engravings) are automatically identified and shown in yellow. (For interpretation of the references to colour in this figure legend, the reader is referred to the web version of this article.) their age (6000 years) and state of conservation, the unique complexity of the engraved compositions and their exceptional distribution all over the walls of the tomb, the lack of space for recording equipment, as well as the presence of engravings on hidden parts of the stones.

The methodology presented here combines laser scanning for the recording of art, stones and architecture, and several types of enhancement techniques for 3D point clouds and photographs for the identification of both content and sequence of the engravings. As it will be argued in this article, these techniques are not used in separate and cumulative manner, but rather in a complementarity perspective: their results complement each other and can be combined in order to create a final, comprehensive and accurate digital model of the decorated tomb.

\subsection{Lasergrammetric recording and post-processing of point clouds}

A review of experiments in three-dimensional recordings of megalithic monuments in Europe since the 1980s (Cassen et al. 2013) underlined the difficulties encountered by archaeologists in using and processing spatial geometry data. Projects are often limited to description by the archaeologists of immediate, dramatic 3D images produced by the technicians. Though the potential for further uses of 3D data for architectural analyses and reconstruction, or representation of megalithic art, is commonly cited, this potential is not applied in most cases as archaeologists usually cannot manage and process such data.

As an exception, the international reputation of a site like Stonehenge has given rise to a series of remarkable experiments, with increasing accuracy and quality of representation (Goskar et al., 2003; Abbott and Anderson-Whymark, 2012). Also notable are key scientific objectives such as measurement of erosion (Field and Pearson, 2010), the study of which is crucial for rock art research. The presence of paint on the walls of megalithic monuments raises similar issues. Recent work on the Neolithic passage tomb of Dombate in Spain shows how a combination of lasergrammetric, photogrammetric and orthophotographic techniques can identify and locate the agents that threaten the paintings and carvings on the walls (Carrera Ramírez, 2011). However, our own experience of lasergrammetry applied to the recording of Neolithic steles and tombs (Cassen and Merheb, 2005) revealed how, as archaeologists, we need to master post-acquisition processes if we are to make real progress in the identification and representation of 


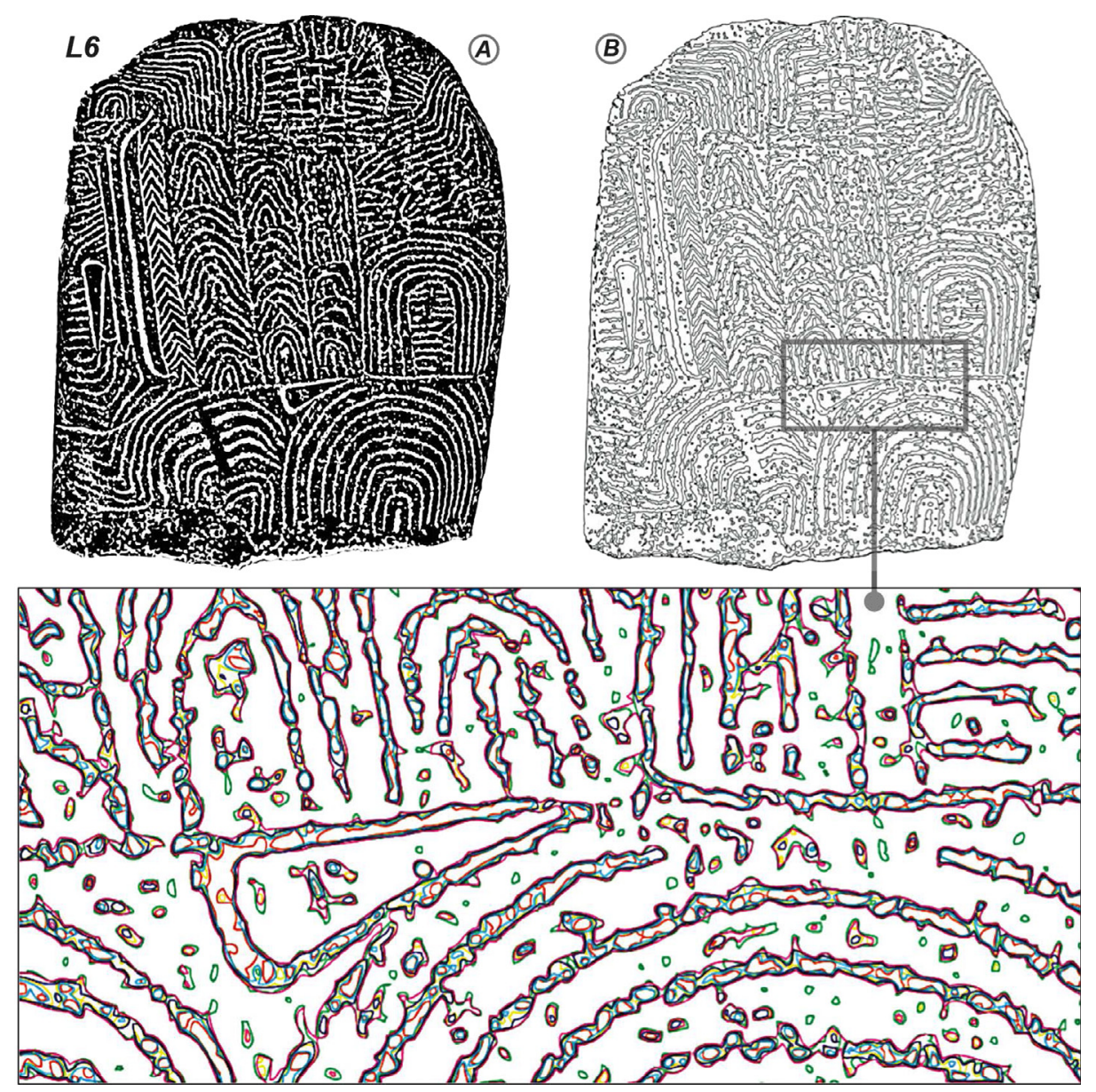

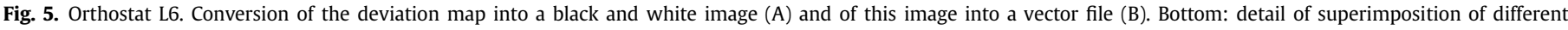

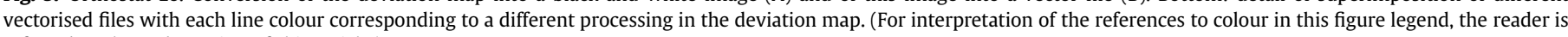
referred to the web version of this article.)

the Breton engraved signs. Consequently, we think that a more lasting dialogue between archaeologists and specialists of 3D programmes applied to architecture is a mandatory prerequisite for the achievement of comprehensive 3D recordings of prehistoric sites. The collaborative work between archaeologists and architects presented in this paper is an illustration of this point.

Thus we first considered lasergrammetry as the best technical option for Gavrinis in order to record both the volumes of the architectural structure and the details of the carvings on the wall surface. Two different kinds of equipment were complementarily used to record the site in order to cover the different scales, from details of the engravings to the whole cairn:

- A Leica Geosystems C10 laser scanner was used for the outer surfaces of the cairn and the whole megalithic structure inside it, with an accuracy of $1 \mathrm{~cm}$ to $1 \mathrm{~mm}$ for the outside and $1 \mathrm{~mm}$ for the inside. Six stations were needed around and on top of the cairn in order to cover the monument almost entirely. Eight stations were made inside the cairn, in the megalithic passage and chamber, as well as in the modern room built over the large chamber capstone whose upper face is engraved. The relative position of each station was recorded using markers placed outside the cairn.

- A Nikon Krypton K610 handheld scanner was used for more detailed recording of each decorated stone, with a $1 \mathrm{~mm}$ accuracy for the passage and chamber orthostats, and $0.5 \mathrm{~mm}$ for the upper face of the engraved capstone. This represents a total of
$12,475,898$ points for the chamber orthostats, $15,262,464$ for the orthostats on the left side of the passage, $15,989,798$ for those on the right side, 28,671,111 for the ceiling and 2,766,463 for the paved floor.

All scans were geographically referenced (Lambert and IGN 69 reference systems) and integrated into a single spatial model. Data (point clouds) were saved in ${ }^{*}$.xyz and ${ }^{*}$.stl (meshed) formats.

More challenging and experimental was the post-acquisition processing of the data. Taking into account essential parameters such as processing time, data volume, mesh repartition and exportation, and the enhancement of the engravings, the reverse engineering software Geomatic (Studio version) proved to be the most effective. Let us take orthostat L6 as a case study. When opening L6 point clouds in the software, one notices that the default meshing of the data automatically created (Fig. 3, A) is not really satisfactory. A bitmap capture of this view was consequently created and processed in Adobe Photoshop (saturation/level/curves) to obtain a better rendering of the natural relief of the orthostat.

In order to make visible the form and extent of the engravings, three types of visual documents were created: a deviation map (Geomagic), a bitmap image of the deviation map combining HD and tensed meshing (Adobe Photoshop), and a vectorised version of the latter (Adobe Illustrator). All images were given the same orthogonal point of view in order to compare their results and to combine them. 

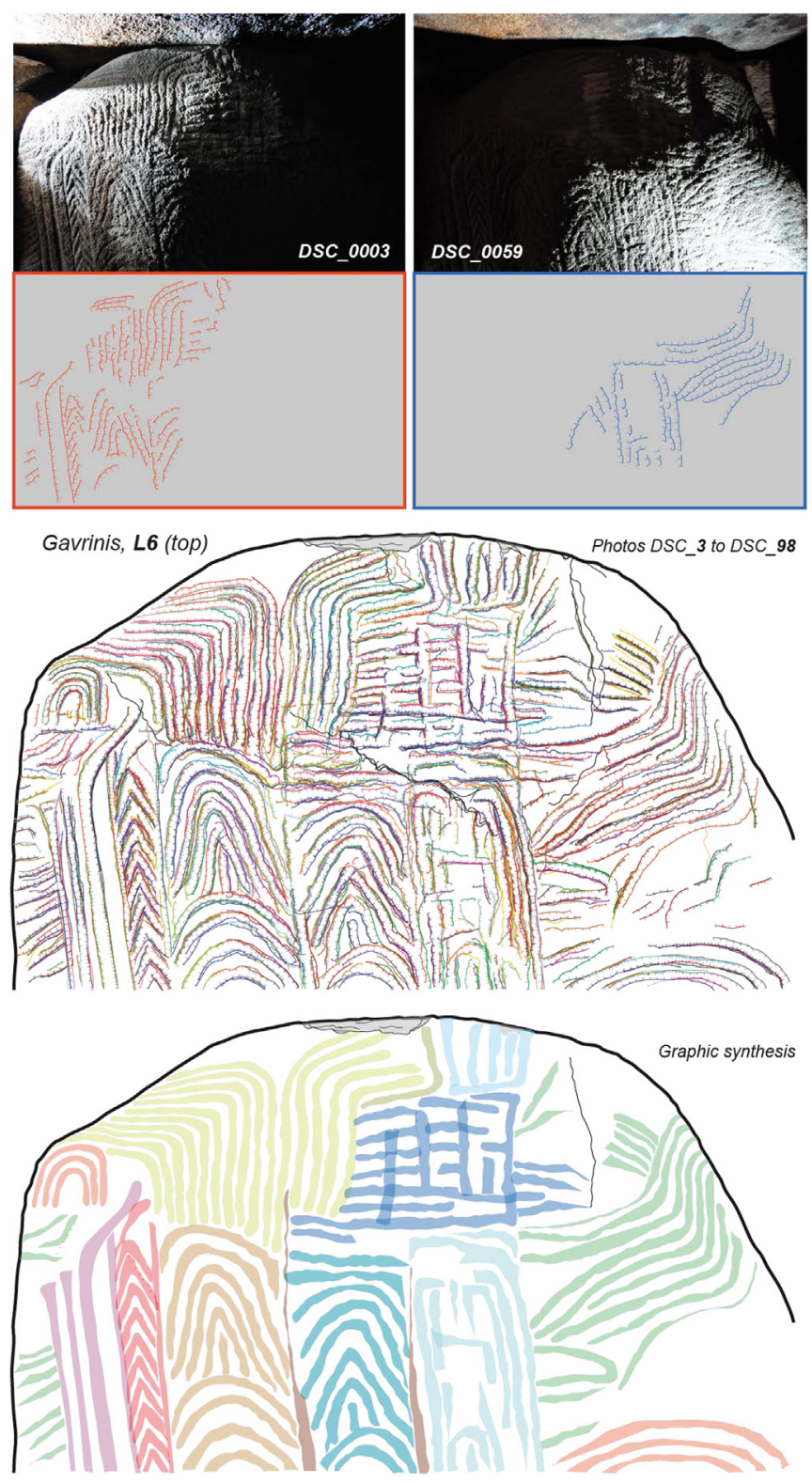

Fig. 6. Orthostat L6. Top: Example of photographs with oblique lights with corresponding vector drawing of the engravings. Middle: superimposition of all the vector drawings, resulting in a synthesis showing the contours of the engravings. Bottom: preliminary illustration of the recording results, showing groups of signs in different colours. (For interpretation of the references to colour in this figure legend, the reader is referred to the web version of this article.)

The first document is called a deviation map (Fig. 4). It enables assessment of the distances between a high definition (HD) meshing of the point cloud, containing very detailed information on the surface, and a smoothed (i.e. homogenised) meshing.

The deviation map consists of a colour code ranging from red (on areas where the smoothed surface is located above the HD surface), to dark blue (where the smoothed surfaced is below the HD surface), and green (where smoothed and HD surfaces are very close to each other). This results in a colour gradient, which represents the distances in millimetres from the smoothed to the high definition surface. The novelty of applying this technique to Neolithic art is that the colour code makes it possible to show the engravings in yellow, and sometimes in red for the most pronounced reliefs.
The second document is a bitmap capture of a combined view of HD and tensed meshing in Geomagic, which is subsequently converted in greyscale in Adobe Photoshop. Yellows and reds (i.e. engravings) are converted into white, while the rest of the stone surface is converted into black (Fig. 5, A).

The third document consists of a vectorised version of the second document, created in Adobe Illustrator (Object/Live Trace/Make and Expand). This enables one to create automatically vector line drawings of the outer contours of the pecked motifs highlighted in the second document (Fig. 5, B). Vectorised versions made with different settings can be superimposed and be given different colours in order to provide further details on pecked contours (see detail in Fig. 5). The resulting file is regarded more as a prerecording or pre-analysis of the art. It is used as an initial drawing basis, the details of which can be transformed and adapted as further recording investigations are made with other techniques, and from which a final drawing of the engravings is eventually produced.

\subsection{Photography with oblique lights}

The second recording technique used at Gavrinis is a 2D photographic technique, which enables identification of very faint engravings by means of oblique lighting and computer processing of photographs. A detailed description of this method, which has been used in several megalithic art sites in northwest Europe, has been published elsewhere (Boujot et al. 2000; Cassen and Robin, 2010). The following section will focus on its application at Gavrinis and its complex engraved compositions.

Maintaining orthostat L6 as a case study, 98 photographs ${ }^{1}$ were taken from the same station and with oblique lights from different sources and angles in order to make visible the various engravings all over the stone surface. The edges of the pecked lines revealed by light contrasts on the photographs were subsequently drawn manually with a digital tablet in Adobe Illustrator, using vector lines with short offset barbules showing the inside of the pecked line (Fig. 6, top). The different drawings were then grouped together in a single file that provides a first overview of the process (Fig. 6, middle).

The final synthetic drawing (Fig. 6, bottom), which has slight focal distortions due to the camera, was eventually distorted in order to refit with the map of the stone made from the 3D point cloud. This can be done either with Adobe Illustrator (Free Transform tool) or Adobe Photoshop (Edit/Transform/Distort) using the bounding box handle of the selected part of the image.

A limit of the oblique light technique appears when distance is missing between the light source and the engraved stones, which may happen in a megalithic tomb like Gavrinis. It is not easy to record the totality of engravings covering the entire surface of orthostats, especially those located towards the edge of the stone or towards the ground, as the light is obscured by adjoining orthostats and capstones. The light, consequently placed too close to the engraved areas, makes them overexposed in the photographs, and opposed directions of light are not possible. Such problems, not often encountered so far in Brittany where stones are rarely entirely

\footnotetext{
1 The equipment used is as follows: Camera body: Nikon D5000; Lens: Nikon $10.5 \mathrm{~mm} \mathrm{f} / 2.8 \mathrm{G}$ ED DX Fisheye-Nikkor; Remote control; Kaiser (StarCluster) LED torch, day light (5600 K; 500 lux); A4 Wacom (Intuos) drawing tablet. Photographic settings: ISO 200; RAW format; Aperture at 16. The difficult shooting conditions inside the tomb (maximum distance less than one metre for photographing stones of $0.70-1.78 \mathrm{~m}$ wide and $1.44-1.75$ high) imposes the use of a very wide angle lens (fisheye). Correction of the deformations resulting from the use of such a lens is now widely available thanks to various softwares such as Nikon Capture, Adobe Photoshop or Image Trends (Hemi).
} 


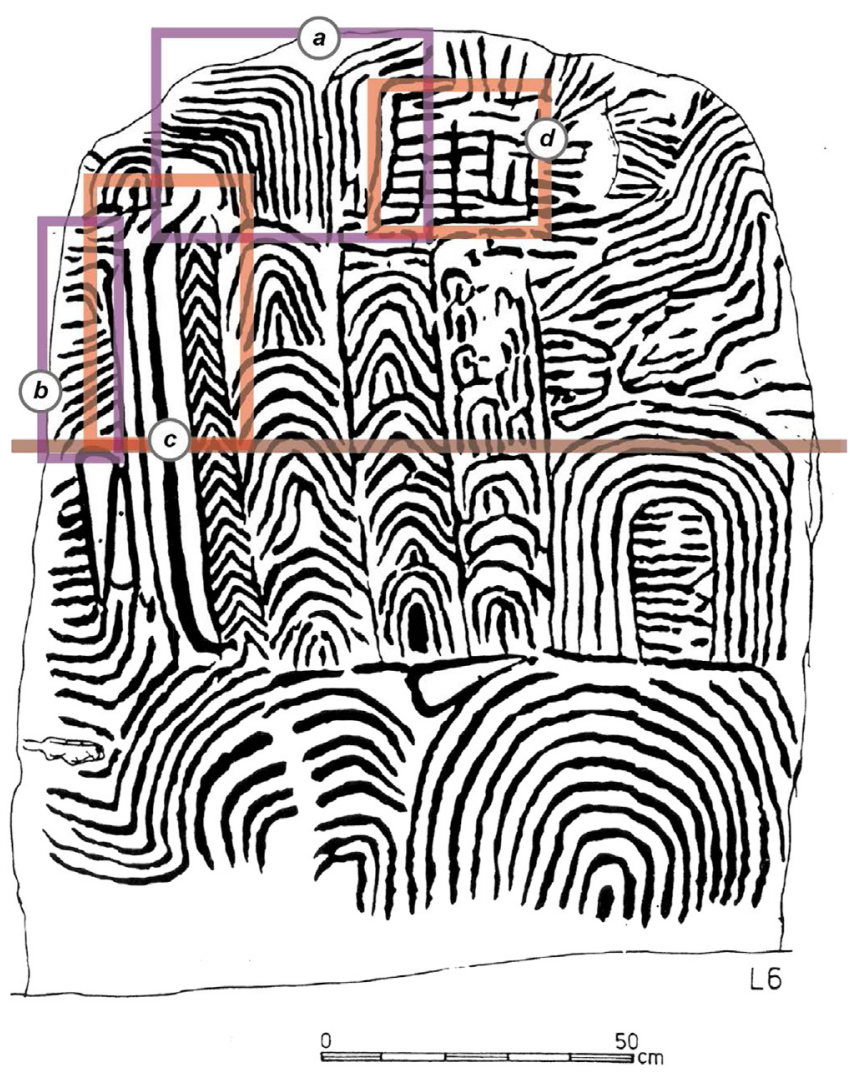

Fig. 7. Orthostat L6. 1981 drawing by Elizabeth Shee Twohig with frames showing areas discussed in Fig. 10.

engraved, show the limitations of the recording technique in confined spaces (see the missing parts of the recording in Fig. 6, especially on the right edge of the stone).

\subsection{Comparing techniques}

In order to assess the advantages and limitations of the different techniques described above, a comparative study of four recording results (lettered A-D), focussing on the top part of orthostat L6, was undertaken.

A. The first recording discussed here is the drawing (the best in the corpus) executed by Shee Twohig (1981) with direct tracing on cellophane sheets (Fig. 7).
B. The second recording is the synthesis resulting from the oblique light technique (Fig. 6, bottom). The result presented here is a minimum recording, as the usual complete process implies additional photographic recordings focussing on problematic areas where details of the engravings are missing.

C. The point cloud obtained by lasergrammetry can be processed with different softwares in order to produce two types of recording of the engravings:

- C1: the first one is produced with the free software Meshlab and uses virtual oblique lighting on the 3D model in a similar way as for the photographic technique (Fig. 8). Despite several limitations (meshing errors and exportation failures for heavy files, limited perspective view), Meshlab, contrary to Geomatic, offers precise settings for the positioning of lighting (Render/Shader/Lattice/Light position). This makes it possible to detect engravings and draw them manually. A total of 36 views were drawn to produce a synthetic recording (Fig. 9).

- C2: the second recording is made in Geomatic and uses the principle of the deviation map. As described above, the deviation map makes clearly visible the contours of the pecked motifs, which were subsequently drawn with a digital tablet in Adobe Illustrator (Fig. 10).

We can now examine the convergences and differences between the four techniques. To do so we will compare the results obtained for four selected motifs located on the top half of orthostat L6, (Fig. 11).

At first glance, the recordings all seem very similar, hence confirming the remarkable character of the recording work executed by E. Shee Twohig. However, a few comments need to be made about details in the carvings in all sectors (a, b, c, d). The conclusions presented below result from thorough and contradictory examinations, as well as on-site checking of the original engravings.

\footnotetext{
- Sector a: in three areas (indicated by arrows in Fig. 11), carvings recorded by E. Shee Twohig were not recorded by the other techniques; these were finally recognised as natural features of the rock. Similarly, the recording made from the deviation map in Geomatic has automatically produced an additional 'engraving' which proved to be an artefact of the device.

- Sector b: the photographic recording has clear limitations for the carvings at the edge of the stone where several pecked lines were not recorded. Fig. 6, however, shows that the technique was able to recognise the lower edges of these pecked lines but failed in identifying their top edges, an opposed oblique light being impossible in this area.
}

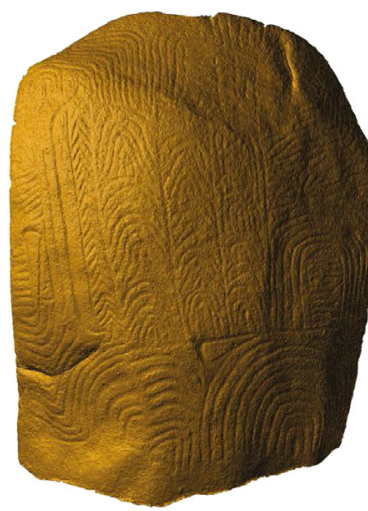

$(-2 / 1 /-1)$

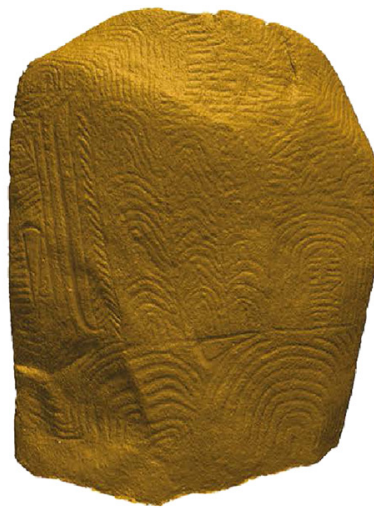

$(1 / 5 / 0)$

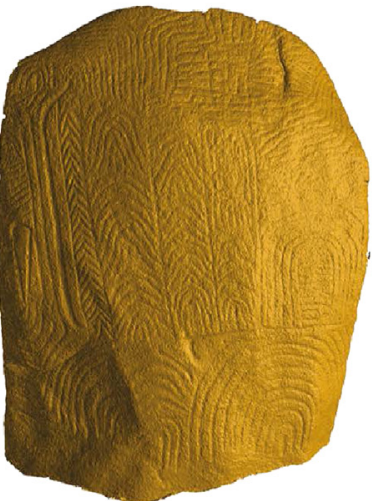

$(5 / 0 / 0)$

Fig. 8. Views of 3D model of orthostat L6 in Meshlab, using three different virtual light settings. 
- Sector c: the top end of the two signs on the left (interpreted as two arrows associated with the adjoining bow) were not accurately recorded by the direct tracing technique (Shee Twohig), whereas the three other techniques perfectly identified them as transverse arrowheads, a typical lithic technology of Neolithic Western France (Guyodo, 2005).

- Sector d: here Geomatic failed to identify a very faded vertical pecked line less than $0.5 \mathrm{~mm}$ deep, and the drawing by Shee Twohig did not record the whole of this reticulated motif. Only a combination of the recordings using real or virtual oblique lights (Fig. 11, d1) makes it possible to reconstruct the totality of the engraved motif.

To sum up, all these techniques have different strengths and limitations, and the better way to use them is to combine their results to create a single recording product. Photography and point clouds should therefore be used to produce complementary recordings of Neolithic pecked stones within a single methodological procedure. We should also point out that, in this multiple methodology, a large number of visible details from the contour of an engraved line does not mean a more accurate recording: if the deviation map technique enables one to produce a much more detailed drawing than the oblique light technique (Fig. 12), the latter provides more information and is more pertinent because it involves the superimposition and synthesis of several drawings.

We will now present a major achievement of these techniques, the reconstruction of the chronological sequence of the execution of the signs.
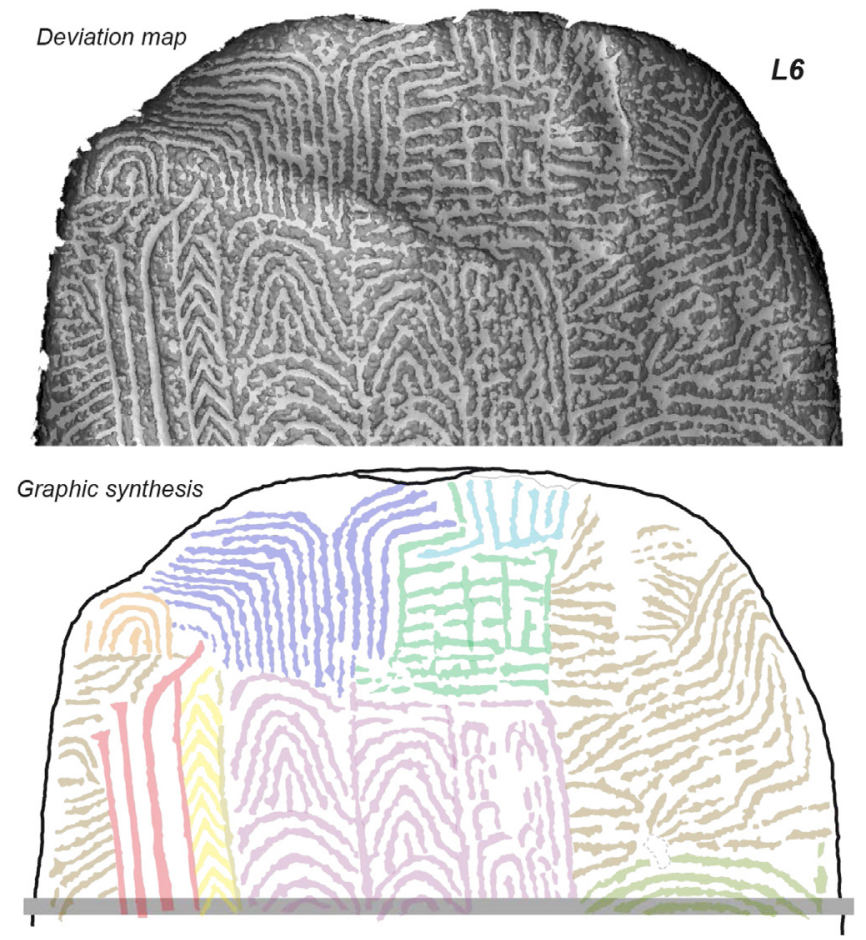

Fig. 9. Orthostat L6. From top to bottom: 3D model with virtual side oblique lighting as viewed in Meshlab; compilation of vector drawings made from 36 images of the 3D model with various oblique lights; same result with vector offset lines showing the contour and inside part of the motifs; graphic synthesis with preliminary colour distinction of groups of motifs. (For interpretation of the references to colour in this figure legend, the reader is referred to the web version of this article.)
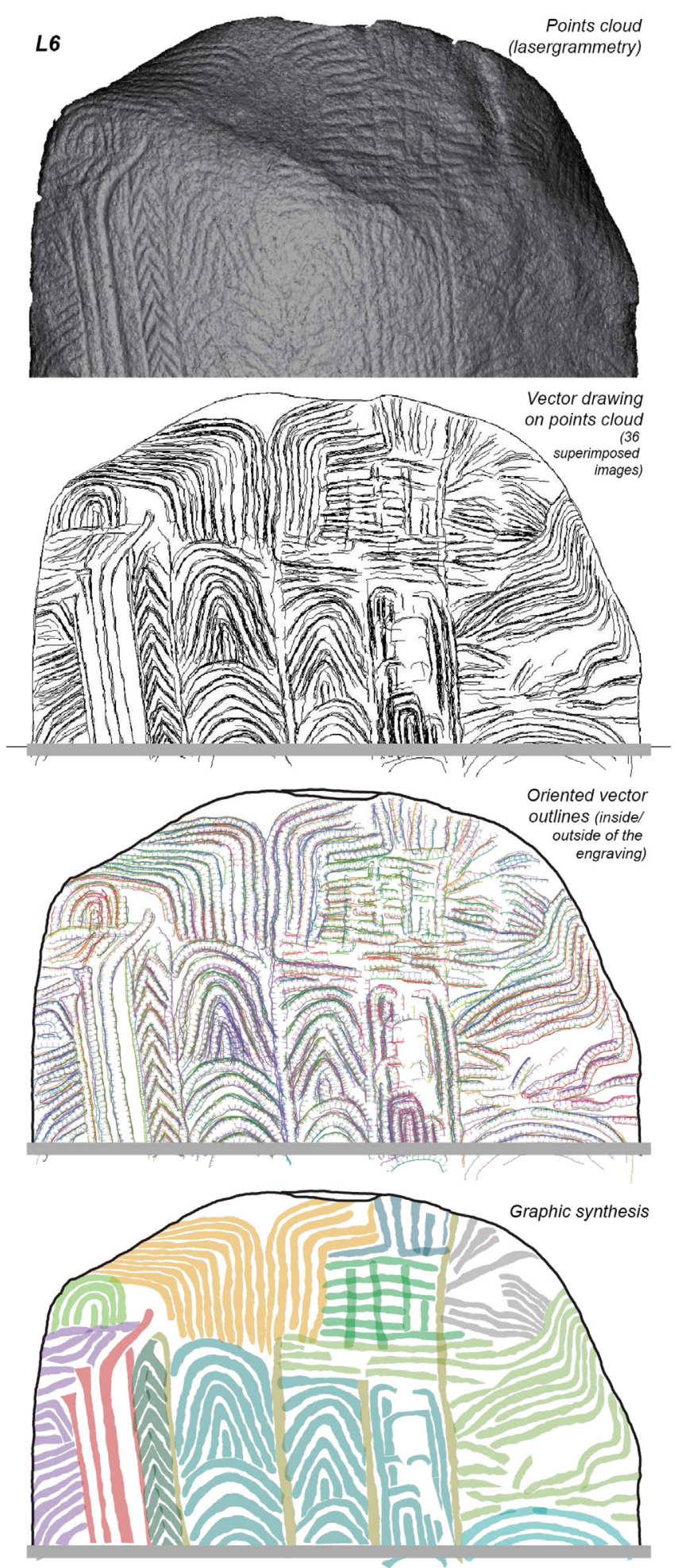

Fig. 10. Orthostat L6. Example of a deviation map showing the contour of the engraved lines, and corresponding vector drawing.

\section{The chronological sequence of the engravings}

The two reference documents here are, on one side, the deviation map, on which overlapping engraved lines (with a latter line cross-cutting an earlier one) are already visible, and, on the other side, the vector drawing made from the deviation map. An 

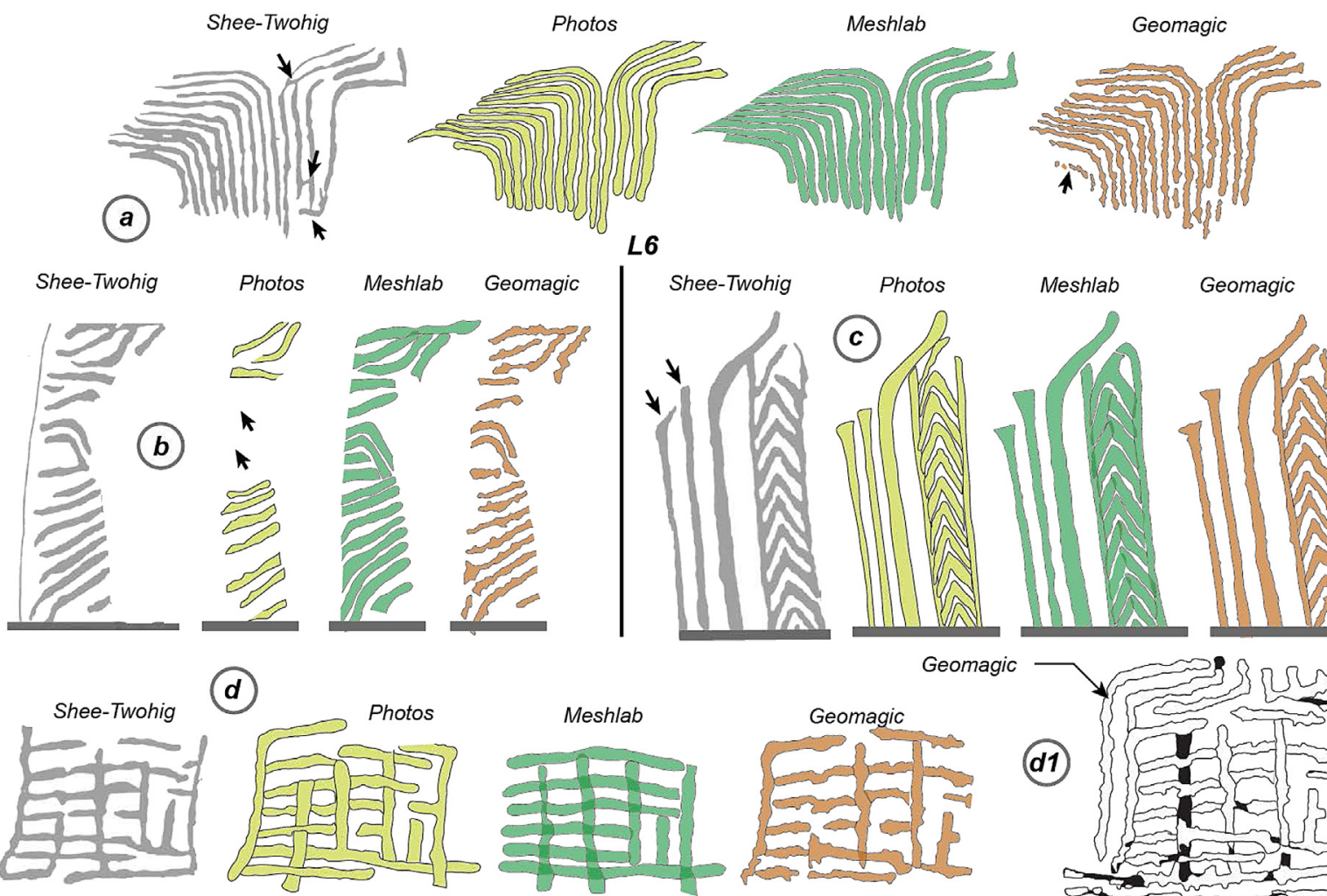

Photos + Meshlab

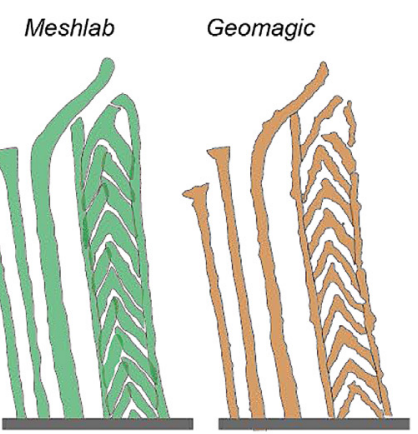

(d)
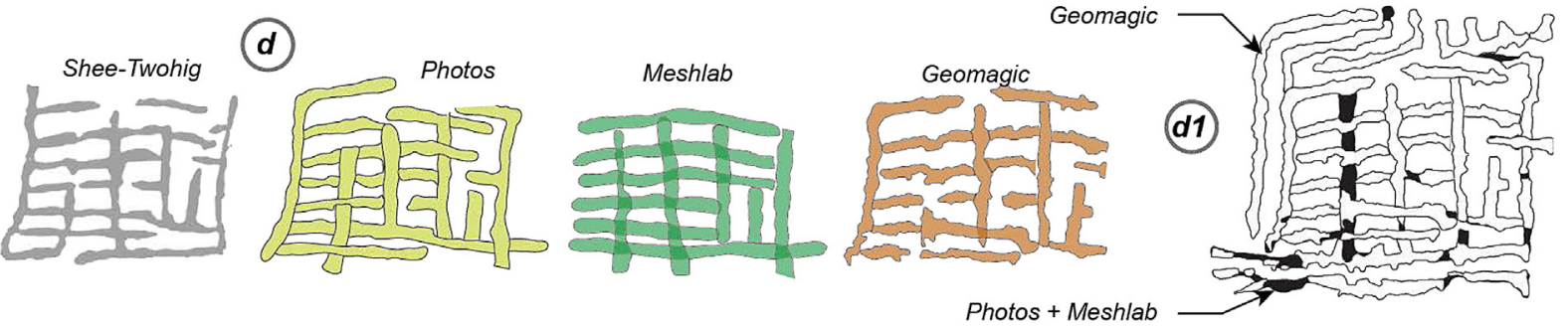

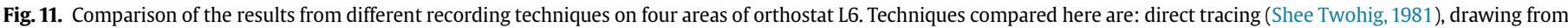

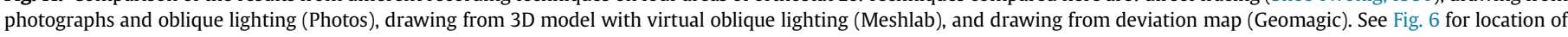
areas a, b, c, d on orthostat L6.

inventory of intersecting engravings on L6 and an examination of the corresponding crossing or contact points makes it possible to infer the chronological sequence of the engravings.

Four different situations were recognised:

1 Cross-cutting of engraved lines: the edges of the later line are marked inside the hollow of the earlier one (Fig. 13, 1).

2 Removing of surface material, when a later sign overlaps on earlier one (Fig. 13, 2).

3 The negative track of an earlier engraved line which, even very faded, affects the form of a later engraving at their crossing points (Fig. 13, 3).

4 An engraved line avoiding another one, which must be interpreted as the result of two distinct phases (Fig. 13, 4). Though this last case is not as demonstrative as the previous ones, and should be used in moderation, it can be included in the reconstruction of the chronological sequence of the engraved composition.

Situations 2 and 3 cannot be identified by lasergrammetric recording, which uses a resolution of $0.5 \mathrm{~mm}$, nor by the deviation map created in Geomagic, or by virtual oblique lights created in Meshlab. Only photographic recording with actual oblique lights has the potential to identify such features, for example in situation 3 (Fig. 13, 3) whose recording required no less than 41 photographs.

From these contact situations, chronological relationships can then be established between motifs or groups of associated signs (less often between individual signs). An order of execution can be deduced in which several entities, termed as semiotic, are placed in relation to each other. For example, the earliest engravings (phase B in Fig. 14) consist of rectilinear signs that were executed from right to left. Their arrangement divides the surface of the stone, using natural features of the rock surface (Fig. 14, A). During the subsequent phase $C$, all the figurative motifs (bow, arrows, polished axe heads) were executed, here again from right to left (Fig. 14, C). The following phases $D-G$ correspond to the execution of the abstract geometric motifs (Fig. 14, D-G).

From the homogeneous technical signature of the engravings it seems clear that all the art executed on L6 is a single project and event. Consequently, the sequence detailed above should be understood as a short-term chronology (or "chronography") showing the successive steps in the execution of the engraving project. Distinct stylistic periods (Shee Twohig, 1981, 64; O'Sullivan, 1996) have not been identified for this particular stone. The results of this chronography can be efficiently synthesised into a matrix showing the succession of the different semiotic entities and the sequence of the main phases (Fig. 14, bottom right), in the same way as a Harris matrix summarises the stratigraphy of an archaeological site. ${ }^{2}$

\section{Recording faint engravings on hard stones: limitations of inframillimetric techniques and unexpected solutions provided by colour enhancement techniques}

Orthostat R11 is a hard sandstone, a material rarely used at Gavrinis where most of the stones in the megalithic structure are grained rocks of granite and gneiss type. The engravings on R11 are

\footnotetext{
2 See Loubser (1997) and Marretta et al. (2011) for a use of Harris matrix showing the superimposition sequence of rock paintings and incisions.
} 


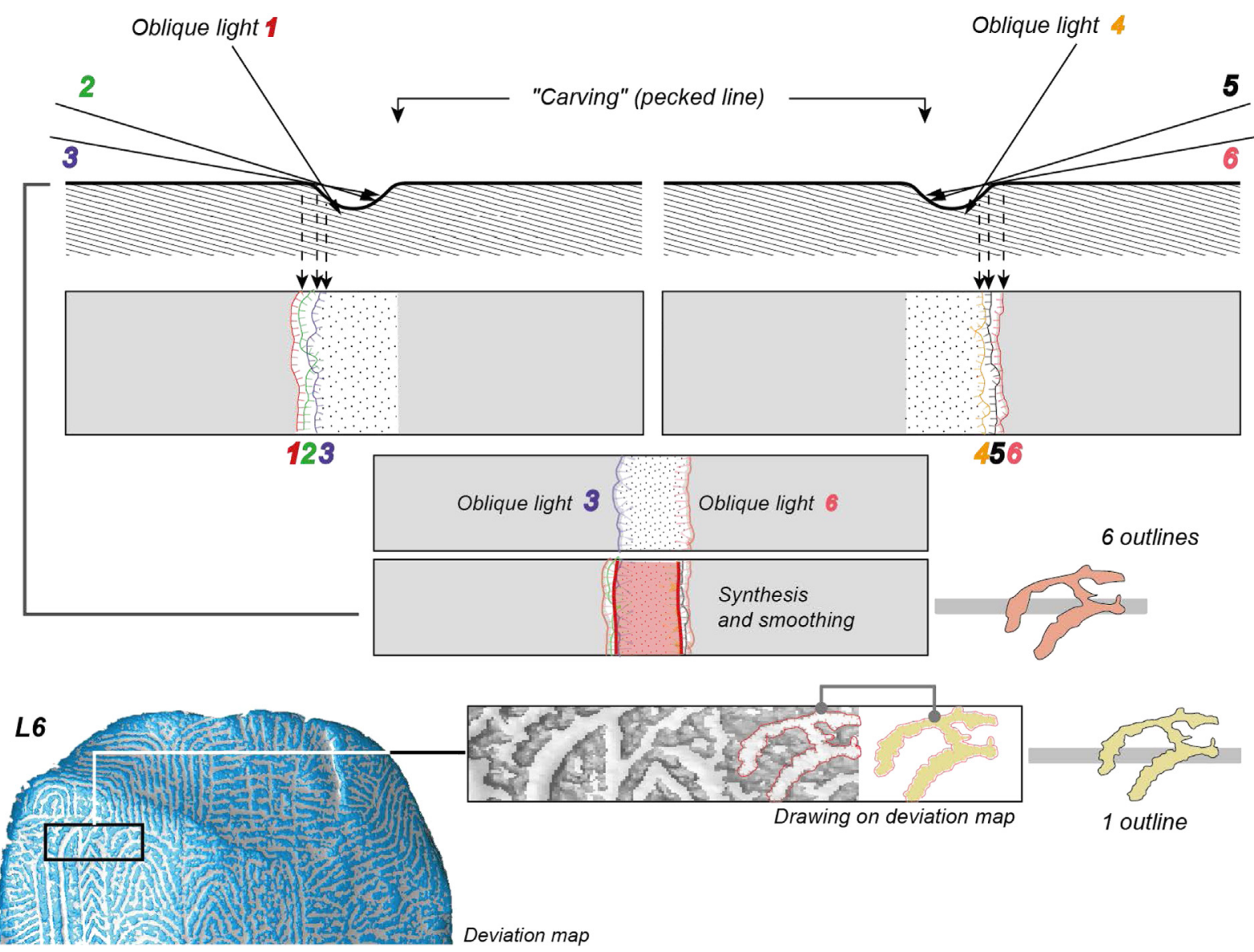

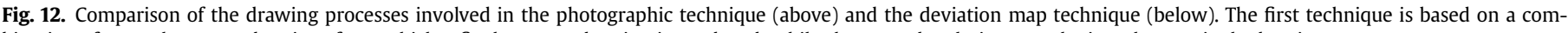
bination of several contour drawings from which a final average drawing is produced, while the second technique results in only one single drawing.

consequently much fainter than the ones made on the other stones of the tombs, and identifying them proved to be a technical problem. While the art of all other engraved orthostats was immediately visible on the monitor screen during the scanning process, without any particular light arrangements, only a very few engravings shown in E. Shee Twohig's drawing appeared on the point cloud.

\subsection{The results of the lasergrammetric and oblique light techniques}

Naked-eye perception of the engravings on R11 depends on the hygrometry rate inside the monument. During dry weather with an easterly or northerly wind, some engravings are visible on the top and bottom part of the stone (see photograph A in Fig. 15), corresponding to the most clearly recorded engravings in Shee Twohig's drawing of the stone (Fig. 15, B). During humid weather with a prevailing wind from the ocean, all the engravings are virtually invisible to the naked eye.

Not surprisingly, the deviation map technique completely failed to identify the engravings (Fig. 15, C). This is due to the very faint depth of the pecked marks (c. $0.1 \mathrm{~mm}$ ), less than the maximum resolution of the scanner $(0.5 \mathrm{~mm})$ which, before being tested on that particular case, was considered as accurate enough. Even engravings visible with the naked eye were not recorded by the scanner.

We consequently decided to use the oblique light photographic technique. A series of 267 photographs was undertaken, an exceptional number which demonstrates in itself all the difficulties encountered in making the engraved reliefs visible with oblique lighting. A synthetical drawing was nevertheless completed (Fig. 15, D). Although new engravings were identified on the lower and left part of the stone, the whole process turned out to be long and difficult, and even uncertain at some points.

\subsection{Colour detection using DStretch}

As noted above, the nature of the engravings on R11 is quite different from the rest of the tomb. They are executed with hollowed pecked lines but rather than a superficial crushing of the rock surface (Fig. 16, A and B), resulting in lightness (light on dark) and texture (matt and coarse on the glossy and smooth surface of the weathered sandstone) contrasts. Based on these particular visual characteristics, an experiment was attempted using a colour detection technique.

The software used is ImageJ (Abramoff et al. 2004), a public domain Java-based programme. Besides medical imagery, its original field of application, it is now routinely used for the recording of painted rock art (Gunn et al. 2010) with the plug-in DStretch (Harman, 2008, version 7.1; http://www.dstretch.com), whose principle is to detect and enhance colour differences. It is quite unconventional to use the technique to identify faint peck-marks instead of pigments, but the result for orthostat R11 at Gavrinis was immediate and striking (Fig. 16, C).

Thirteen photographs were processed in order to obtain complementary information and a good restitution of the engraved surface. The carvings visible on the photographs were drawn separately in Adobe Illustrator, and then grouped together to 

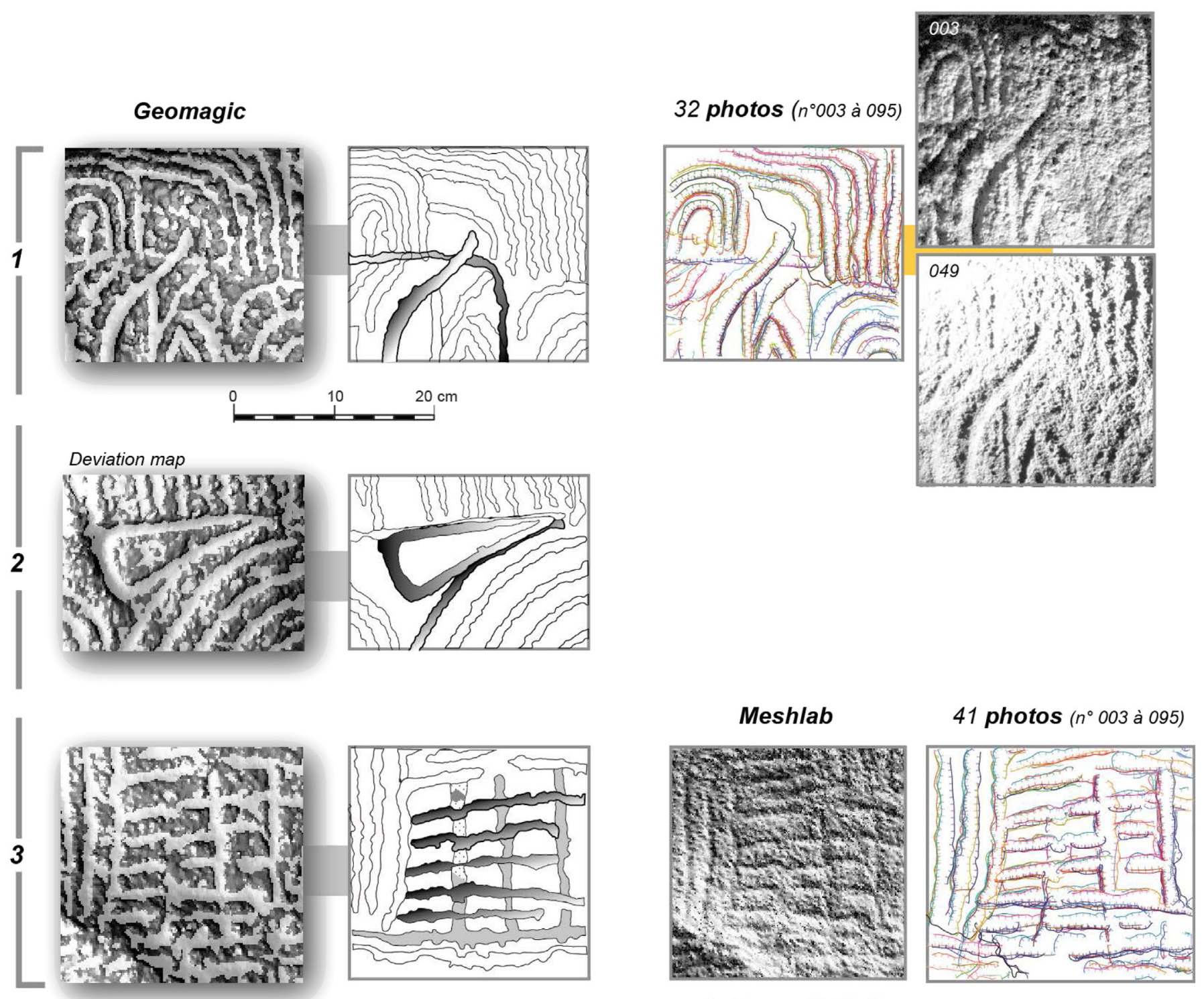

(incidence $=40,50,0$ )

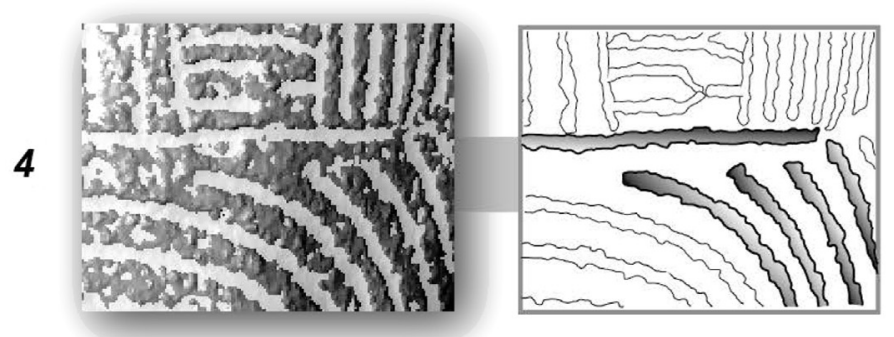

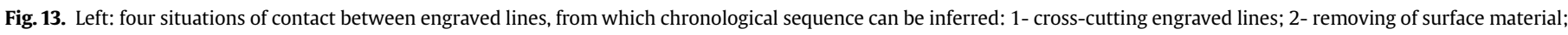

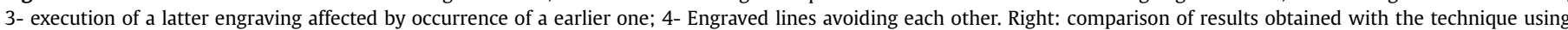
photographs and oblique lights (top) and the technique using 3D model and virtual oblique lights in Meshlab (bottom).

produce a final synthesis of the recording process, revealing many more elements and details than previous recordings (Fig. 16, D).

\section{Conclusions}

As a preliminary to reinterpretation of the symbolic representations in the Gavrinis passage tomb, some of the most famous
Neolithic art in Western Europe, the creation of a new corpus of the engravings was considered to be a priority. Not only have the signs to be identified on the surface of the stones, but they also have to be understood in their architectural context (the funerary chamber, the access passage, the covering cairn) and in the volume of the individual stones (the orthostats forming the walls). The present article describes recording techniques for the engravings and these 

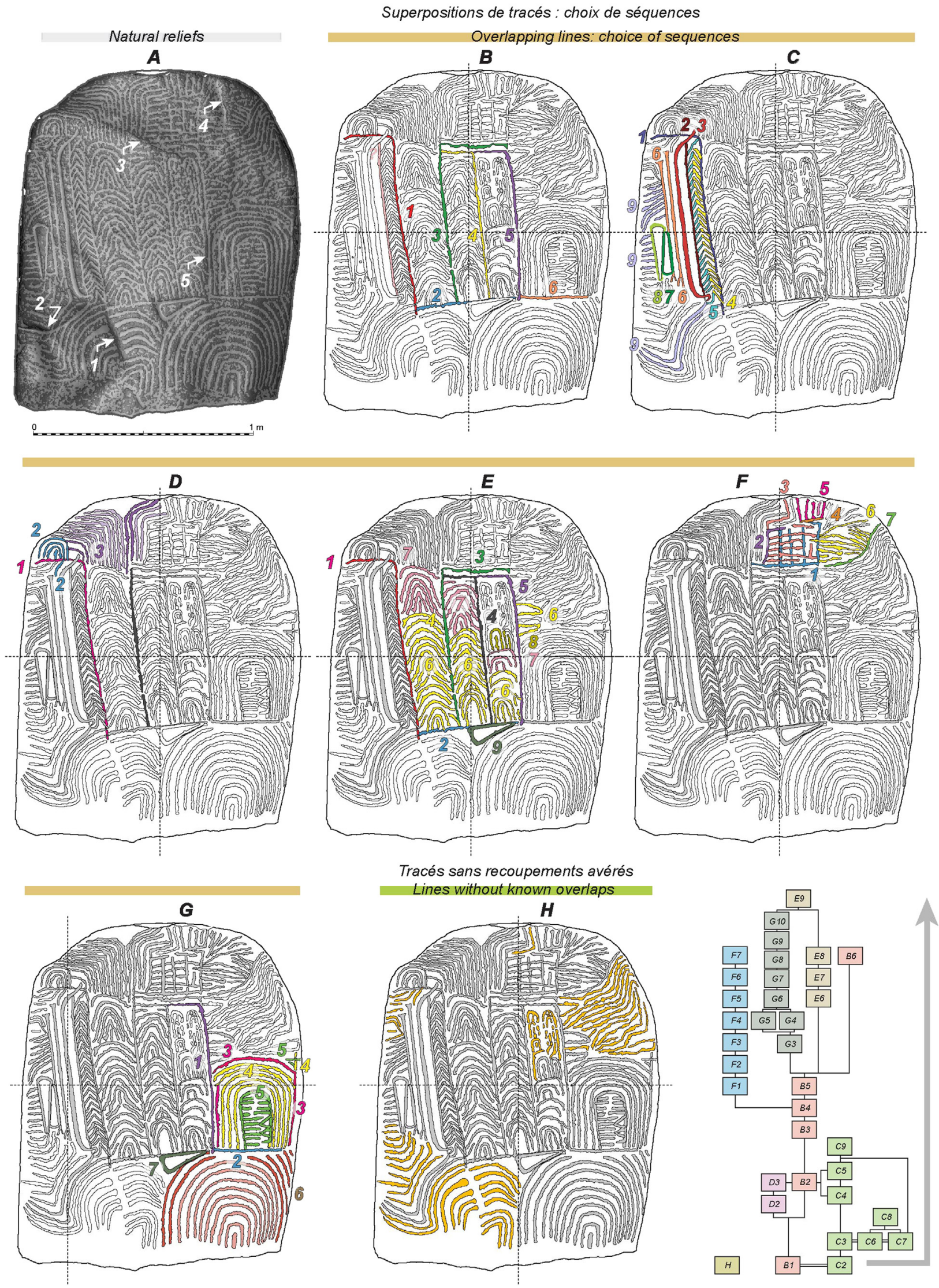

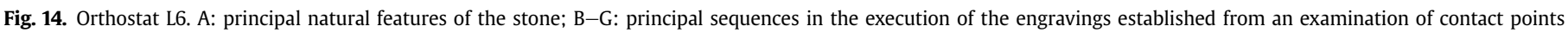

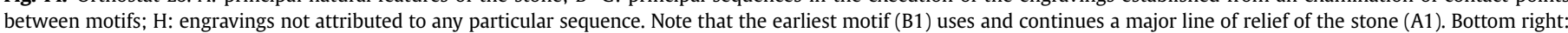
chronographic matrix of the main phases of art execution on L6. 

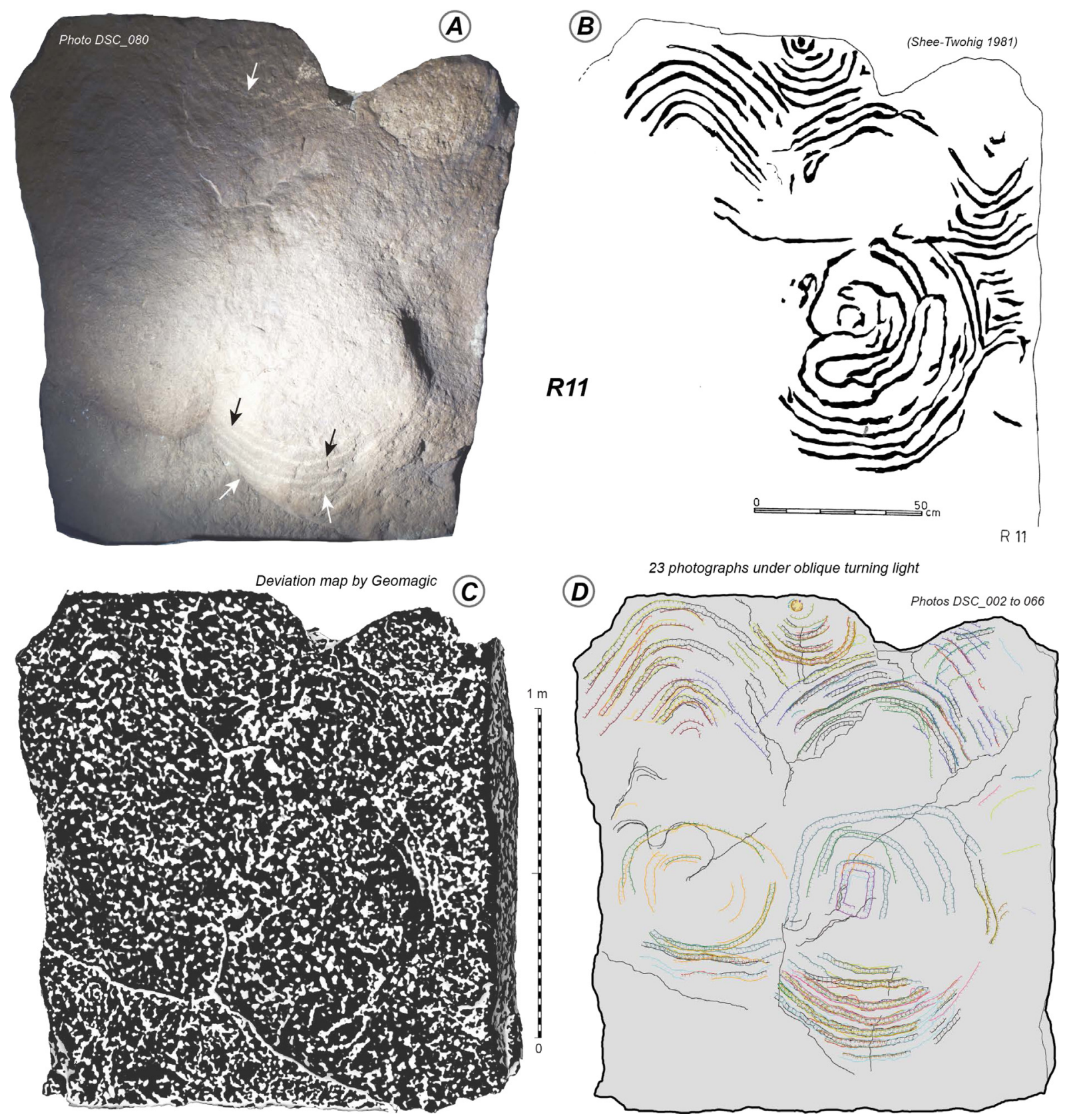

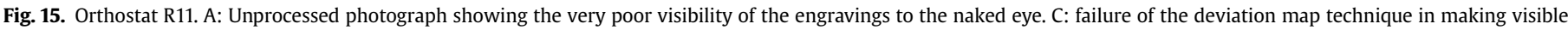
the engravings. D: recording of the engravings with the photographs and oblique lighting technique compared to A: recording by Shee Twohig (1981).

techniques are just one component of the multiscalar approach to the monument. The ultimate objective is to find the internal dynamics within these engraved compositions, as well as possible hierarchical relationships between the signs.

The reference document for each decorated orthostat is a georeferenced point cloud generated by lasergrammetry with a millimetric resolution. One technical challenge is to find the appropriate balance between recording accuracy and a reasonable size of the digital files making feasible their processing and operating. Each file is about 250 Mo for one orthostat ranging from 0.70 to 1.80 width and 1.40 to 1.80 height, while engravings are generally $2-3 \mathrm{~mm}$ deep.

Using the complex engravings of orthostat L6 as a case-study, we have described an innovative archaeological application of the deviation map. The image produced with this technique highlights the engravings as hollowed lines and serves as a guide for the manual vector drawing of the art using a drawing tablet. In order to compare the results of the deviation map technique and of the photographic and oblique lighting technique, the latter method was applied to orthostat L6, for which 98 photographs were taken. The limitations of the method are obvious on the edges of the stones where oblique lighting is impossible or obscured by adjoining elements such as the ground floor, the ceiling, or protruding orthostats, forcing the light source to be placed close to the stone and resulting in overexposure of some areas. This limitation is problematic at Gavrinis but not in other megalithic art contexts in 5th and 4th millennium BC Western France, where engravings are usually not made all over the surface of the stones. 

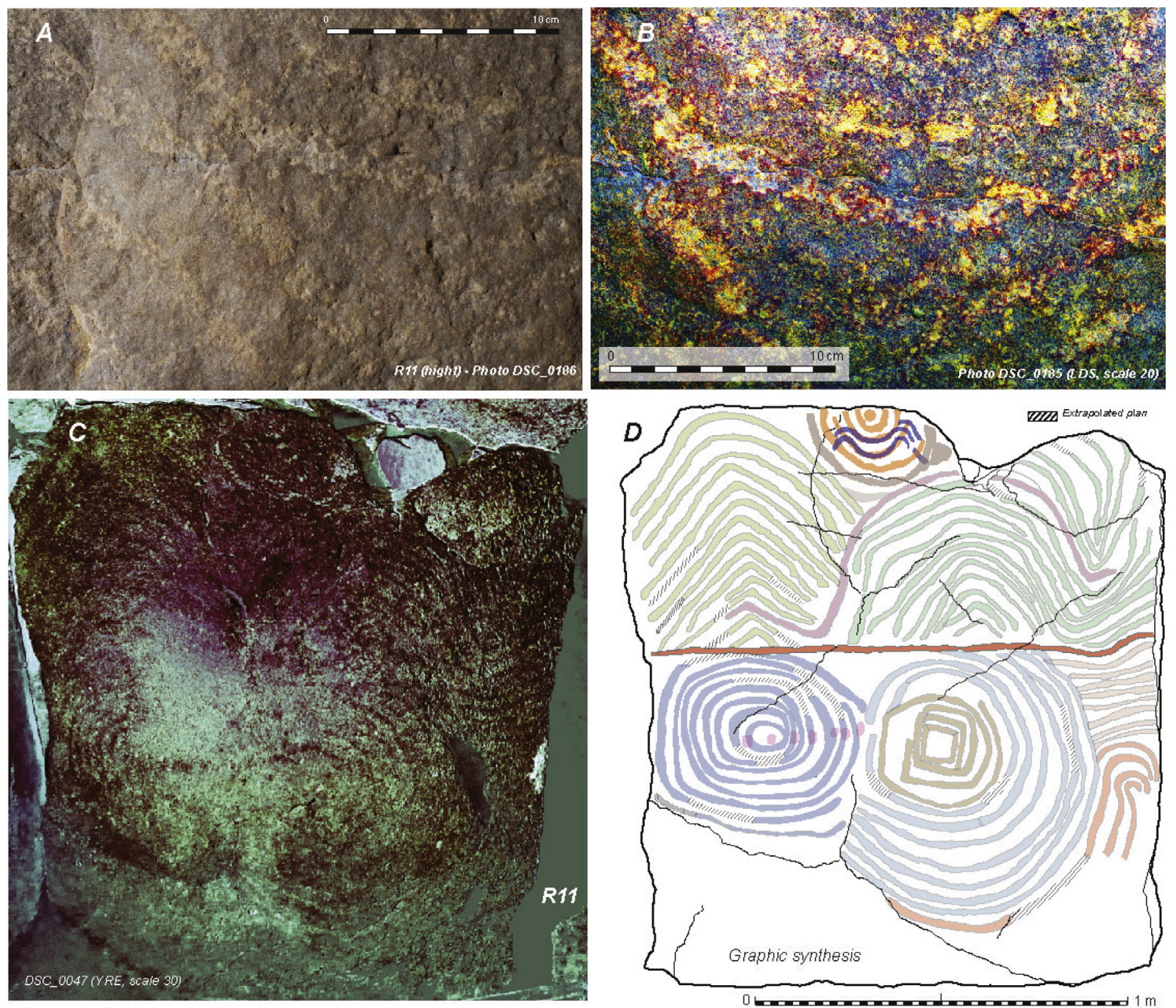

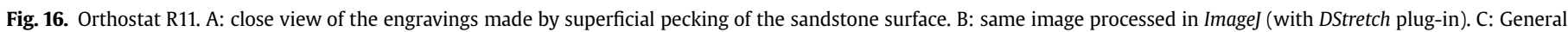
view of the stone processed in ImageJ. D: resulting synthesis drawing (with correction of lens distortion).

In fact, the photography and oblique lighting technique proved to be more effective than lasergrammetry for the identification of anteriority/posteriority relationships between signs. Despite the high resolution $(0.5 \mathrm{~mm})$ of the laser scanner, the resulting 3D point cloud did not highlight these relationships apart from the deepest cross-cutting lines, and virtual oblique lights on the model did not answer all questions on the diachrony of the engravings, particularly for the most eroded ones. Only the processing of photographs taken with oblique lights provided enough detailed information about the engravings and their chronography, making it a necessary and complementary technique to lasergrammetry.

Although Neolithic engraved art in Brittany is often difficult to record in an accurate and comprehensive way, two of the 25 decorated orthostats at Gavrinis are even more difficult to record because of the sandstone material. Recent experiments conducted by Marie Vourc'h and Cyrille Chaigneau at Gavrinis have shown that deep pecked engravings ( $2-3 \mathrm{~mm}$ deep) are easily and rapidly ( $1 \mathrm{~cm}$ by minute) executed on granite, which is a grained rock. Sandstone, however, with its agglomerated quartz grains, offers much more resistance to pecking, which was not able to produce similar engravings as on granite. On sandstone, engraved lines can only be very faint $(0.1 \mathrm{~mm})$ and are only visible from the colour difference between the natural and pecked surfaces. Consequently, recording techniques based on lasergrammetry and photographs with oblique lighting failed to discern engraved figures that are still visible to the naked eye in good hygrometric conditions. Based on the idea that the visibility of such engravings during the Neolithic depended on lightness contrasts between the pecked surfaces (light colour, almost white) and the raw rock surface (weathered dark yellow colour), an experiment was conducted using a programme for colour enhancement processing of photographs (ImageJ). The technique, working on colourspace, made it possible to recognise a large number of ancient engravings, invisible today with the naked eye, and ultimately to record nearly twice as many engravings as had been previously known.

The first lesson of this methodological research on Neolithic art documentation techniques is that comprehensive recording and representation of the engravings, from the decimetric scale of the stone reliefs to the inframillimetric scale of the pecking, cannot be achieved by any of these techniques if they are used separately. Only a combined use of lasergrammetric and photographic techniques can achieve this objective. The second lesson is that an interpretative work on the signs engraved in Neolithic tombs should not be based only on a simple static representation of the 
motifs but also on a detailed reconstruction of their spatiotemporal dynamics or chronography. The techniques described in this paper are particularly effective in producing a reconstruction of this kind.

\section{Acknowledgements}

We are grateful to Dr. Marie Vourc'h (LARA, Université de Nantes) and Cyrille Chaigneau (Musée de Carnac) who provided data from their ongoing experiments on Neolithic engraving techniques. We would like to express our warm thanks to Michael Ilett (Paris 1 Panthéon-Sorbonne University) for his revision of the translation of this paper. The research programme directed by Serge Cassen ("Gavrinis: à la recherche des représentations d'une tombe à couloir du IVe millénaire") is funded by the Département du Morbihan, the Ministère de la Culture (DRAC Bretagne, ENSA Nantes) and the CNRS, with technical support from the Sagemor.

\section{References}

Abbott, M., Anderson-Whymark, H., 2012. Stonehenge Laser Scan: Archaeological Analysis Report. Research report series $n^{\circ} 32$. English Heritage, Fort Cumberland, Portsmouth.

Abramoff, M.D., Magelhaes, P.J., Ram, S.J., 2004. Image processing with ImageJ. Biophot. Int. 11 (7), 36-42.

Boujot, C., Cassen, S., Defaix, J., 2000. La Pierre décorée du caveau et les gravures régionales nouvellement découvertes. In: Cassen, S. (Ed.), Eléments d'architecture, Mémoire 19. Editions chauvinoises, Chauvigny, pp. 277-297.

Carrera Ramírez, F., 2011. El arteprehistórico y su conservación. Pinturas y grabados en Dombate. In: Rodríguez, J.Y. (Ed.), El dolmen de Dombate : arqueología, arquitectura y conservación. Deputación da Coruña, A Coruña, pp. 230-266.

Cassen, S., 2000. Architecture du tombeau, équipement mortuaire, décor céramique et art gravé du Ve millénaire en Morbihan. A la recherche d'une cosmogonie des premières sociétés agricoles de l'Europe occidentale. In: Jorge, V.O. (Ed.), Actas do $3^{\circ}$ Congresso de Arqueologia Peninsular, Vila Real 1999, Pré-historia recente da Peninsula ibérica, vol. IV. ADECAP, Porto, pp. 447-479.

Cassen, S. (Ed.), 2009. Autour de la Table. Explorations archéologiques et discours savants sur une architecture néolithique restaurée à Locmariaquer, Morbihan (Table des Marchands et Grand Menhir). Université de Nantes, Nantes.

Cassen, S., 2011. Le Mané Lud en mouvement. Déroulé de signes dans un ouvrage néolithique de pierres dressées à Locmariaquer (Morbihan). Préhist. Méditerr. 2, $1-58$.

Cassen, S., L'Helgouac'h, J., 1992. Du Symbole de la crosse : chronologie, répartition et interprétation. In: Le Roux, C.T. (Ed.), Paysans et Bâtisseurs. L'émergence du Néolithique atlantique et les origines du Mégalithisme. Actes du XVIIe colloque interrégional sur le Néolithique. Vannes 29-31 octobre 1990. Revue Archéo. de l'Ouest (Suppl. 5), 223-235. Rennes.

Cassen, S., Merheb, M., 2005. Stone surfaces, earth surfaces: notes about the recording and the 3D representation of engraved steles within Neolithic funeral structures in western France (Locmariaquer, Carnac - 4700-3800 cal. BC.). In: Dobrovolskaya, M. (Ed.), Mejedistsplinarie Issledovania v Arkheologii, Interdisciplinary Investigation in Archaeology, vol. 4. OPUS, Moscow, pp. 182-191.

Cassen, S., Robin, G., 2010. Recording art on Neolithic stelae and passage tombs from digital photographs. J. Archaeol. Method Theory 17 (1), 1-14.

Cassen, S., Lescop, L., Grimaud, V., 2013. Pour une critique de la représentation tridimensionnelle des architectures mégalithiques en Europe occidentale. Méthodes et usages actuels. Ann. Bretagne Pays l'ouest 120 (1), 7-31. http://
www.academia.edu/4008990/Pour_une_critique_de_la_representation_ tridimensionnelle_des_architectures_megalithiques_en_Europe_occidentale Methodes_et_usages_actuels.

Closmadeuc, G. (de), 1873. Sculptures lapidaires et signes gravés des dolmens dans le Morbihan. Imp. De Lamarzelle, Vannes.

Closmadeuc, G. (de), 1884. Gavrinis. Fouilles et découvertes récentes. Bull. Soc Polymat. Morbihan 2, 180-187.

Closmadeuc, G. (de), 1885. Image d'un quadrupède sculptée sous la Table du DolVarc'hant - Dolmen dit des Marchand ou de César, Locmariaquer. In: Matériaux, t. 2, pp. 453-455.

Closmadeuc, G. (de), 1886. Gavrinis. Dernières fouilles sous le dallage de la chambre. Bull. Soc. Polymat. Morbihan 2, 63-69.

Domingo, I., Villaverde, V., López-Montalvo, E., Lerma, J.L., Cabrelles, M., 2013. Latest developments in rock art recording: toward an integral documentation of Levantine rock art sites combining 2D and 3D recording techniques. J. Archaeol. Sci. 40, 1879-1889.

Field, D., Pearson, T., 2010. Stonehenge World Heritage Site Landscape Project. In: Stonehenge, Wiltshire, Archaeological Survey Report, Research Department Report Series, vol. 109. Amesbury.

Goskar, T., Carty, A., Cripps, P., Brayne, C., Vickers, D., 2003. The stonehenge lasershow. Br. Archaeol. 73. http://www.britarch.ac.uk/ba/ba73/feat1.shtml.

Gunn, R.G., Ogleby, C.L., Lee, D., Whear, R.L., 2010. A method to visually rationalise superimposed pigment motifs. Rock Art Res. 27 (2), 131-136.

Guyodo, J.-N., 2005. Les assemblages lithiques de la fin du Néolithique ancien et du Néolithique moyen sur le Massif armoricain et ses marges. In: Marchand, G. Tresset, A. (Eds.), Unité et diversité des processus de néolithisation sur la façade atlantique de l'Europe (6è - 4è millénaires avant J.-C.). Actes de la table-ronde de Nantes, 26-27 avril 2002, mémoire n³ 36. Société Préhistorique Française, Nantes, pp. 213-224.

Harman, J., 2008. Using Decorrelation Stretch to Enhance Rock Art Images. Article online: http://www.dstretch.com/AlgorithmDescription.html.

Le Roux, C.-T., 1984a. À Propos des fouilles de Gavrinis (Morbihan). Nouvelles données sur l'art mégalithique Armoricain. Bull. Soć. préhist. francaise 1 (8) $240-245$.

Le Roux, C.-T., 1984b. New excavations at Gavrinis. Antiquity 59, 183-187.

Le Roux, C.-T., 1985. Gavrinis et les îles du Morbihan. In: Guides archéologiques de la France. Ministère de la Culture, Paris.

Loubser, J.H.N., 1997. The use of the Harris diagrams in recording, conserving and interpreting rock paintings. Int. Newsl. Rock Art 18, 14-21.

Lescop, L., Cassen, S., Grimaud, V., 2013. Gavrinis. The raising of digital stone. In: Addison, A.C., De Luca, L., Guidi, G., Pescarin, S. (Eds.), Digital Heritage International Congress (Marseille, France), CAA Fall 2013 Symposium, Communicating Archaelogy: Theory \& Practice, vol. 2, pp. 561-568.

Marretta, A., Martinotti, A., Colella, M., 2011. Nuove metodologie di documentazione e analisi sequenze istoriative su due frammenti litici con graffiti protostorici da Piancogno (Valcamonica, Bs). In: Papers of the XXIV Valcamonica Symposium 2011, pp. 294-305.

Mérimée, P., 1836. Notes d'un voyage dans l'Ouest de la France. Éd. Adam Biro, 1989 Paris.

O'Sullivan, M., 1996. Megalithic art in Ireland and Brittany: divergence or convergence. In: L'Helgouac'h, J., Le roux, C.-T., Lecornec, J. (Eds.), Art et symboles du mégalithisme européen. Revue Archéologique de l'Ouest (Suppl. 8), 81-96. Rennes: Association pour la diffusion des recherches archéologiques dans l'ouest de la France.

Pinçon, G., Geneste, J.M. (Eds.), 2010. Art rupestre : la 3D un outil de médiation du réel invisible?. In Situ, Revue des patrimoines 13. URL: http://insitu.revues.org/ 6150 [last accessed 28.10.13.].

Pétrequin, P., Cassen, S., Errera, M., Klassen, L., Sheridan, A., Pétrequin, A.M., 2012 Jade. Grandes haches alpines du Néolithique européen. Ve et IVe millénaires av. J.-C. Cahiers de la MSHE C.N. Ledoux. Presses Universitaires de Franche-Comté et Centre de Recherche Archéologique de la Vallée de l'Ain, Besançon. vol. 2.

Shee Twohig, E., 1981. The Megalithic Art of Western Europe. Clarendon Press, Oxford. 